\title{
Effects of External Public Debt Cancellation on the Economic Growth of the Republic Of Congo
}

\author{
Lauric Ngouembe $^{1}$, Jean-Anaclet Mampassi ${ }^{2}$ \\ ${ }^{1,2}$ Marien Ngouabi University of Brazzaville and Lares \\ Corresponding author: Ingouembe @gmail.com
}

Received: January 29, 2021; $\quad$ Accepted: February 06, 2021;

Published: 28 February 2021

\begin{abstract}
This study, through temporal data and the ARDL process, examined the effects of the cancellation of external public debt on economic growth in the Republic of Congo over the 1990 to 2016 period. From this review, it appears that debt cancellation has a positive impact on economic growth over the short-term and a negative impact over the long term. Beyond these results, we believe that additional research is needed to examine the channels through which external public debt cancellation influence economic growth in the Republic of Congo.

Keywords: Debt cancellation, growth, Congo
\end{abstract}

JEL Classifications: H63; F43; 055

\section{Introduction}

Over the past two decades, the economic context of all subSaharan African countries has been marked by excessive debt; to the point where, since 2014-2016, it has become a major concern for the countries of the CEMAC zone (Economic and Monetary Community of Central Africa), for heads of state, international institutions and donors. According to the International Monetary Fund (IMF, 2019), the economies of these countries have suffered drastically from the effects of falling oil prices, which have resulted in slower economic growth, lower budget revenues, rapidly increasing public deficits, erosion of foreign exchange reserves and a tightening of bank liquidity. The credibility of CEMAC countries vis-à-vis the international financial community has been undermined by their unsustainable debts in view of their insufficient solvency.

In 2017, the Fund's Executive Board approved three-year arrangements for Cameroon, Chad and Gabon and also increased its support under the Extended Credit Facility (ECF) by three years for the Central African Republic. In 2018, the Republic of Equatorial Guinea received support from IMF staff to begin implementing a similar program. Meanwhile, the Republic of Congo recently signed an agreement in July 2019 with the IMF, from which it obtained assistance to resolve its internal and external imbalances being to finance its balance of payments imbalance, to restore the external stability of its economy, to strengthen its fiscal sustainability, and re launch its development program (NDP).

In fact, since the 1980s to date, the Republic of Congo's external debt management has not been underpinned by a logic of accumulation of productive capital from the point of view of debt capacity, strengthened by a poor orientation of investments made from the oil revenue, with dubious macroeconomic profitability, due to lack of significant diversified development of agricultural and agro-industrial activities, including the export sector. Thus, the State's debt policy has, on the other hand, pushed the government into a vicious circle of external financing, with the perverse effects of massive cuts in domestic resources (national savings), budgetary revenues and foreign exchange reserves.

Since the debt crisis of the 1980s, the international financial community has been deploying efforts to help debtor countries reduce their external debt burden in order to promote growth, reduce poverty and achieve external sustainability.

The Republic of Congo has benefited from a number of debt relief measures during this period to restructure and cancel its external debt, in line with changes in oil revenues (including the economic crises). More especially, by the end of 2010, the country had reached the completion point of the Heavily Indebted Poor Countries (HIPC) initiative and benefited from significant external debt cancellation, reducing its GDP ratio from 199\% (2004) to $20 \%$. Subsequently, it experienced rapid growth in this ratio by the end of 2017 (80.5\%), leading to a debt overhang, thereby bringing the overall rate or total public debt ratio to $117.9 \%$ of GDP.

Whereas, economic literature has struggled, from the 17th century to date, to close the debate on the nature (positive, negative or zero) on the effects of public debt as well as its partial or total cancellation on economic growth. We therefore have two groups of economists that continue to oppose each other : the optimistic economists (keynesians), on the one hand, who support the existence of a positive relationship, and the pessimistic economists (classical and/or neoclassical) on the other hand, who insist on the neutrality (that is a negative relationship) of the debt and its de facto cancellation on economic growth. 
This opposition is what leads us to analyse their respective hypotheses (optimistic and pessimistic) within the macro-economic context of the Republic of Congo, while supporting the thesis that the cancellation of external public debt has a positive impact on the economic growth of this country.

To achieve this, the article is divided as follows: part two gives a simultaneous overview of both situations, the external debt cancellation and economic growth, in the Republic of Congo from 1990 to 2016; therefore, the third section presents a review of the different theoretical and empirical approaches to the issue of debt cancellation; then, the methodological approach, the model estimation and interpretation of the results make up the forth part; and finally, the last part includes the conclusions and the implications of the economic policies.

\section{The external debt cancellation and the economic growth situation in the Republic of Congo}

The presentation of the stylized facts covers the periods 19801989, 1990-1999, 2000-2010 and 2011-2018 through changes in external debt indicators on the one hand and, changes in economic growth punctuated by some restructuring and cancellation of external debt, on the other hand. This periodization takes into account the different steps of macroeconomic development marked by economic and external debt crises, as well as the agreements with the International Monetary Fund that led, at the end of the five-year plans (1982-1986, 1990-1994) or during the IMFsupported programmes (1986-88, 1992-94, 2003-2010), to restructuring and/or cancellation of external debt.

\section{i. Trends in external debt}

The total external debt (TED) of the Republic of Congo from 1970 to 1992 , shows a significant increase (with a coefficient of 34.41) accompanied by a high instability (at $94.38 \%$ ); going from US\$ 124 million (1970) to US\$ 5.125 billion (1987), and rounding up between US\$ 4.763 billion and US\$ 4.22 billion for the rest of the period while remaining relatively significant. The debt ratio (TED/GDP) recorded an upward trend over the period: from $83.47 \%$ in 1981 to $223.05 \%$ in 1987 . In other words, the amount of Congo's total external debt increased faster than the country's real debt capacity. The total long-term debt never fell below 100\% during the period, compared to exports.

Between 1970 and 1979, the relative share of public external debt in the total guaranteed long-term debt exceeded $63.4 \%$. Then, between 1980 and 1990 , this share regressed $(73.72 \%$ to $36.6 \%)$ in favour of private guaranteed long-term loans. In addition, since 2000, public debt as a percentage of GDP decreased from $199 \%$ (2004), to $112.7 \%$ (2007), then to $77 \%$ (2008), before falling to $19.9 \%$ (2010), due to the achievement of the HIPC completion point and all the subsequent relief and cancellation. Congo has thus emerged from its former status as the most indebted country in Africa per capita and is now in a very favourable macroeconomic situation.

The resources thus freed up could have helped finance growth, diversification of the productive apparatus and social sector spending. However, since 2015, the Republic of Congo has been plunged back into economic recession and pandemic poverty. The sustainability of its external debt has thus begun (117\% of GDP in 2018).
This economic and financial situation in the Congo raises questions about the real effects of the cancellation of the external public debt on economic growth in this country.

\section{ii. Status of external debt cancellation and economic growth}

The multiplication of agreements for the development of the external debt of the Republic of Congo is indicative of the significant financial difficulties of the State during the whole period covered by this article.

From 1960 to 1985, the annual growth rate of Congolese real GDP varied between $1.29 \%$ and $50.3 \%$; recording a sharp decline (-6.8\%) in 1986. Between 1982 and 1991, the contribution of gross fixed capital formation (GFCF), which had reached $56 \%$ of GDP in 1982 , to economic growth fell by an average of $-5.62 \%$ per year. Following an agreement with the IMF in 1985, the country obtained the rescheduling of $95 \%$ of its debt maturities for the period 1986-1988, including numerous structural adjustment loans from the Paris Club. In 1990, a series of agreements were signed with the international financial institutions.

GDP growth was slower over the $1980-1990$ period $(+9.48 \%$ on average per year) than external debt growth $(+14.09 \%)$. In other words, the amount of Congo's total external debt grew faster than the country's real debt capacity. In 1992, the Republic of Congo was declared non-performing by the World Bank. In 1993, its external debt service rate was $21.1 \%$ of GDP, whereas the country adopted a policy to increase its indebtedness such that this rate attained $68.6 \%$ in 2006 (UNDP, 2012).

The change in the average annual growth rate over the period 1990 to 2016 shows a downward trend. We notice a relatively high, gradual and accelerated periodic growth of GDP followed by declines; hence a sinusoidal trend. Over the 1990-2000, 20002007, 2008-2009 and 2009-2011 periods, the Congolese average annual growth rates stood at $1 \%, 4.1 \%, 6.4 \%$ and $7.1 \%$ respectively; one created by both the oil and non-oil sectors, despite the periods of crisis that the country has experienced (UNDP, 2012)

Faced with difficulties in servicing its external debt, the Republic of Congo has benefited from various debt cancellation initiatives, with the aim of making its debt levels sustainable and improving its growth rates.

One of these initiatives is the HIPC initiative, which has provided Congo with debt relief ( $80 \%$ of the total) estimated at US\$ 1,575 million for the 2006-2010 period. On the other hand, the Multilateral Debt Relief Initiative (MDRI), launched in 2006 by the Bretton Woods institutions, complements this debt relief process within the framework of the HIPC initiative. The MDRI aims to accelerate progress towards the United Nations Millennium Development Goals and provides $100 \%$ relief on eligible debt from these three institutions: the International Monetary Fund (IMF), the World Bank (WB) and the African Development Bank (AfDB).

In addition, these are the agreements of the Paris and London Clubs and other bilateral negotiations outside the Paris Club. The public debt of the Republic of Congo was estimated at $\$ 5.6$ billion at the end of 2008. The debt owed to Paris Club creditors was estimated at $\$ 2.5$ billion as of January 1, 2010. The Paris Club and Brazil have granted the Republic of Congo a cancellation of \$ 981 million under the HIPC Initiative. In addition, a further cancellation of the principal payments owed to participating creditors, amounting to $\$ 177.7$ million in nominal terms, has been granted through the MDRI, resulting in savings of US\$ 201.3 million for the country from its total external debt service arrears through 2043. These external debt relief or cancellation have led to 
a reduction in the country's external liabilities and an improvement in its external assets and position.

However, despite this relief, Congo's external public debt has quadrupled: it rose from $20 \%$ of GDP in 2010 to $87.8 \%$ of GDP in 2018 , well above the regional ceiling of $70 \%$. Annual debt service is estimated at US\$1.4 billion on average between 2019 and 2022, with China and oil traders accounting for $47 \%$ of this amount (IMF, 2019). The annual economic growth rate, which stood at $+8.7 \%$ between 2011 and 2014, subsequently eroded due to external shocks, caused particularly by the fall in the price of a barrel of oil; thus inducing the economic and financial crisis which is reflected in a considerable drop in growth to $2.8 \%$ in 2015 .

All of the above shows that the Republic of Congo has benefited from substantial reductions in its external debts, which should enable it to release significant resources while the price of a barrel of Brent is at its highest, without any clearly visible effects on its economic growth.

\section{Review of economic literature}

The economic literature on the relationship between external public debt cancellation and economic growth has been the subject of conflicting debates among researchers and economic policy makers as to the nature of this relationship. Some authors, such as Krugman (1988) and Stern (2002), argue that debt cancellation improves the economic performance of the recipient country and stimulates its growth, thanks to improved financial balances and investment incentives as well as new capital inflows. Others, such as Bulow and Rogoff (1989) and Presbitero (2009), take the opposite view, that is, debt cancellation does not improve growth because of deficient institutions and the effect of revealing unsustainable debt.

Indeed, in this section, we present the quintessence of these debates, first at the theoretical level and then at the empirical level.

\section{i. Theoretical review}

For several decades, the study of the impact of the external public debt and thus its cancellation on economic growth has aroused particular interest and important debates among economists. The origin of this theoretical debate is relatively old and can be attributed to one of its pioneers, Cairnes (1874); and its renewal is linked to the theories of endogenous growth. Thus, two main approaches clash: the Keynesians and the Neoclassics.

For the Keynesians (the optimistic current), the main idea here is the existence of the impact of indebtedness for present and future generations, because of the investments it finances. According to this current of thought, in an initial phase, indebtedness makes it possible to revive demand and is a source of leverage accelerating an increase in investment that generates an increase in production. However, in a second phase, the debt service that it generates is a source of deficit for its negative effect on national savings; and therefore, its cancellation would favour future financial balance (between savings and investment). The payment of debt service tends to crowd out government spending, leading to a fall in overall investment, and its future weight, described by the increased tax pressure (Raffinot, 2005).

In other words, the positive effect of debt cancellation on economic growth is at the heart of the theory of debt overhang (Krugman 1988 and Sachs 1989), with solvency (reduction or cancellation of discounted debt) and sustainability (respect for financial commitments) of the over-indebted country as central concepts. According to this theory, reducing debt overhang stimulates growth by improving the country's investment incentives and the inflow of potential new capital.

Conceptually, this idea is embodied in the debt Laffer curve, represented by an inverted " $U$ ", which describes the relationship between the level of outstanding debt and the expected net present value (NPV) of debt service payments. Debt overhang in this context means that a country is to the right of the peak of this curve. In this scenario, reducing the outstanding debt (through debt relief) increases the expected NPV of debt service payments. This suggests that debt relief can reduce the outstanding debt below this peak threshold, restoring the incentive for debtor countries to undertake efficient investments and for new lenders to extend credit. As a result, it improves productivity and growth by increasing investment volumes.

In the same perspective, Corden (1988) suggests that relief decided by creditors may increase the debtor's incentives to undertake reforms and avoid recourse to reimbursement. In the same vein, the crowding out theory (Cohen, 1993) posits that when a country has a high debt burden, debt service payments crowd out investment and thereby impede growth. Thus, debt relief affects growth by freeing up resources that can be used for productive investment.

On the other hand, the classics and neoclassics (pessimistic current) consider debt as a future tax. According to them, public debt has a negative impact on the accumulation of capital and the consumption of present and future generations. Thus, the cancellation of debt is neutral for current generations and does not constitute a bridge between generations because of the anticipation of economic agents on possible future borrowings. Thus, cancelling debt or substituting it for taxes does not necessarily lead to growth.

According to this school of thought, debt relief has no potential in itself to improve economic performance. There are, among others, the reputation effect theory and a number of approaches. With respect to the reputation effect theory, the idea is that debt relief neither improves a country's growth nor stimulates investment because of its impact on the country's reputation in international financial markets. Indeed, it increases uncertainty about future debt service payments and confirms an unsustainable debt burden (Bulow and Rogoff, 1989). On the other hand, it may also increase uncertainty about the government's ability to meet its debt-servicing obligations in the future, thus hindering investment efforts in the country (Servén, 1997).

In the same perspective, Easterly (2002) argues that the debt relief strategy is stronger in developing countries. In fact, once the reductions have been obtained, these countries will seek to accumulate new debts, in the hope of being eligible for new debt relief initiatives. According to the author, there is a problem of moral hazard in the behaviour of the leaders of some heavily indebted poor countries.

\section{ii. Empirical review}

Several empirical studies have been carried out and are arranged according to the two theoretical points of view presented above.

The first (optimistic) group brings together studies that reveal the existence of a positive effect between debt cancellation and economic growth. This group includes studies by Abdelhafidh (2008) who, in examining the effect of external debt reduction on economic growth in 26 low-income African countries, finds that debt reduction has significant effects on growth. However, this only involves reductions in terms of cancellations, and is positive only when debt exceeds $408.53 \%$ of GDP. These results also show 
that it is beyond the amount of debt relief (6.67\% of GDP) that the debt overhang is resolved.

On the other hand, while examining the effects of debt relief on Nigeria's economic growth from 1980 to 2009, Ekpiriware and Oladeji (2012), using a regression technique, obtained results which reveal that debt relief has freed up resources for Nigeria's economic growth. In addition to the above authors, Marcelino and Hakobyan (2014) studied the impact of debt relief on HIPC growth over the 1996-2011 period using an MMG methodology and a growth model by Barro (1999). Their results show that there are positive effects of the HIPC initiative on growth in these countries, but fail to indicate whether this is due to investment or some other channel.

As for the second group (pessimistic), whose studies support the absence of direct or indirect effect of the cancellation of external public debt on economic growth. This is Johansson (2007) who, in determining the impact of debt relief on investment and growth in developing countries over the period 1983-2003, finds that debt relief does not appear to have influenced investment or growth.

After studying the benefits of debt relief on Africa's economic growth using an OLS methodology, the three economists Victor, Johan and Cheh (2009) found that the external debt relief granted does not have the potential to drive economic growth in these countries

Using OLS methodology and a standard growth model, Bakare (2010) studied the impact of debt cancellation on the growth of Nigeria's economy. He obtained results that conclude that Nigeria's debt overhang problem has been alleviated, however, debt service relief has not positively influenced economic growth.

\section{Methodology}

The theoretical model, which serves as our analytical framework, is based on the Mankiw, Romer and Weil's (1992) model developed earlier by Solow (1956) in which, labour is a homogeneous factor, and physical capital the only factor of production that can be accumulated. This function is indicated as follows:

$Y_{t}=K_{t}^{\alpha}\left(A_{t} L_{t}\right)^{1-\alpha}$

Where $Y_{t}, \alpha, 1-\alpha$ and $A_{t}$ denote production, the shares of the remuneration of capital and labour in GDP, and the technology level respectively.

Mankiw, Romer and Weil (1992) developed this model by adding human capital into the production function and modelled this human capital as a determinant of output as follows:

$Y_{\mathrm{t}}=\mathrm{A}_{0} \mathrm{Z}_{\mathrm{t}}^{\theta \mathrm{j}} \mathrm{K}_{\mathrm{t}}^{\alpha} \mathrm{H}_{\mathrm{t}}^{\beta} \mathrm{L}_{\mathrm{t}}^{1-\alpha-\beta} \mathrm{e}^{\mathrm{z}_{\mathrm{t}}}$

$\theta j+$, yt refers to the GDP growth rate, represents the level of technology, Kt represents the capital stock available in the economy, Ht refers to the stock of human capital, Lt represents the quantity of labour, $\mathrm{Zt}$ represents the set of control variables, $\theta$ is the parameter the variable $\mathrm{j}$ retained. Finally, et refers to the stochastic perturbation that captures the effects of other factors not taken into account in the model.

After transformation, we will integrate debt cancellations after decomposing the capital stock into public and private investment. These components represent gross fixed capital formation and external debt cancellations respectively (which is our interest variable). Thus, we obtain:

$$
\begin{gathered}
\ln y_{t}=\ln A_{0}+\theta_{j} \ln Z_{t}+\alpha \ln b_{0}+\alpha b_{1} \ln F B C F t+\alpha b_{2} \ln A n D t+\beta \operatorname{lnh} h_{t}+\varphi \ln L_{t}+\rho(5) \\
\ln y_{t}=\ln B_{0}+\theta_{j} \ln Z_{t}+\alpha b_{1} \operatorname{lnFBCFt}+\alpha b 2 \ln A n D t+\beta \operatorname{lnh} h_{t}+\varphi \ln L_{t}+\rho(6) \\
\text { Where } \rho=\varepsilon+\mu, \ln B_{0}=\ln A_{0}+\ln b_{0}
\end{gathered}
$$

In this work, the variables debt cancellation $(\mathrm{AnD})$, official development assistance (ODA APD in French), total population growth (POPC) and exports of goods and services (XBS) were used to analyze the effect of debt cancellation on the rate of economic growth (GDPC - PIBC in French).

The choice of these variables is justified by the existing literature on the subject. Thus, the dependent variable in this study is the GDP growth rate (PIBC). It provides information on the evolution of economic growth in relation to economic activity in all sectors (Bakare, 2010). According to studies carried out by Abdelhafidh (2008), the debt cancellation variable (AnD) and the total population growth rate (POPC) represent the share of the debt that has been cancelled and the human capital indicator respectively, in order to also monitor the effect of total population on GDP growth. Official Development Assistance (APD) is included to capture the effect of aid other than debt cancellation (Johansson, 2007). Exports are supposed to boost growth by providing resources for public investments that would otherwise not be possible (Bakare, 2010).

Therefore, taking into account our choice of variables, our empirical model for estimation purposes is as follows:
$\mathrm{PIBC}=\mathrm{a} 0+\mathrm{a} 1 \ln (\mathrm{AnD})+\mathrm{a} 2 \mathrm{POPC}+\mathrm{a} 3 \ln (\mathrm{APD})+\mathrm{a} 4 \ln (\mathrm{XBS})+\varepsilon \mathrm{t}$

The data used in this study were obtained from the World Bank's WDI database for Congo. Our econometric estimates cover the period 1990-2016. To reduce the influence of cyclical fluctuations, the total period has been divided into quarters. There are 108 observations in total, hence the possibility of making statistical inference.

The results of the normality and stationarity tests on all our variables are conclusive and justify our choice of the ARDL technique. Thus, after estimation of a simple ARDL model, it appears that the coefficient of determination (R2) is 0.99 and that some control variables are significant, so there is no carry-over effect on the variable of interest. Also, the model validation tests are conclusive. Consequently, the model is well specified.

\section{Presentation and interpretation of results}

\section{i. Presentation of results}

The short- and long-term results from the ARDL model estimates are presented in the tables below: 
Table 1: Short term results

\begin{tabular}{|c|c|c|c|c|}
\hline \multicolumn{5}{|c|}{ CointegratingForm } \\
\hline \multicolumn{3}{|l|}{ Variable } & \multicolumn{2}{|l|}{ Coefficient } \\
\hline \multicolumn{3}{|c|}{$\mathrm{D}(\mathrm{PIBC}(-1))$} & \multicolumn{2}{|l|}{0.918644} \\
\hline \multicolumn{3}{|c|}{ D(LAND01) } & \multicolumn{2}{|l|}{0.008177} \\
\hline \multicolumn{3}{|c|}{ D(LAND01(-1)) } & \multicolumn{2}{|l|}{0.058313} \\
\hline \multicolumn{3}{|c|}{$\mathrm{D}($ LAND01(-2)) } & \multicolumn{2}{|l|}{0.027390} \\
\hline \multicolumn{3}{|c|}{$\mathrm{D}($ LAND01(-3)) } & \multicolumn{2}{|l|}{$0.038813^{*}$} \\
\hline \multicolumn{3}{|l|}{ D(LAPD) } & \multicolumn{2}{|l|}{$-0.273293 *$} \\
\hline \multicolumn{3}{|l|}{ D(LXBS) } & \multicolumn{2}{|l|}{$5.635284 *$} \\
\hline \multicolumn{3}{|c|}{$\mathrm{D}(\mathrm{LXBS}(-1))$} & \multicolumn{2}{|l|}{0.297223} \\
\hline \multicolumn{3}{|c|}{$\mathrm{D}(\operatorname{LXBS}(-2))$} & \multicolumn{2}{|l|}{-3.958460} \\
\hline \multicolumn{3}{|l|}{$\mathrm{D}(\mathrm{POPC})$} & \multicolumn{2}{|l|}{76.920327} \\
\hline \multicolumn{3}{|c|}{$\mathrm{D}(\mathrm{POPC}(-1))$} & \multicolumn{2}{|l|}{314.658934} \\
\hline \multicolumn{3}{|c|}{$\mathrm{D}(\mathrm{POPC}(-2))$} & \multicolumn{2}{|l|}{$-205.332971 *$} \\
\hline \multicolumn{3}{|c|}{ CointEq(-1) } & \multicolumn{2}{|l|}{-0.322073} \\
\hline \multicolumn{5}{|c|}{ Cointeq $=$ PIBC $-(-0.4498 *$ LAND01 + 0.5864*LAPD + 0.3573* } \\
\hline \multicolumn{5}{|c|}{ Source: Authors using Eviews software. } \\
\hline \multicolumn{5}{|c|}{ Table 2: Long term results } \\
\hline \multicolumn{5}{|c|}{ Long Run Coefficients } \\
\hline Variable & Coefficient & Std. Error & t-Statistic & Prob. \\
\hline LAND01 & $-0.449814^{*}$ & 0.162039 & -2.775958 & 0.0107 \\
\hline LAPD & $0.586408^{*}$ & 0.169283 & 3.464074 & 0.0021 \\
\hline LXBS & 0.357272 & 1.040408 & 0.343396 & 0.7344 \\
\hline POPC & $17.636725^{*}$ & 4.828476 & 3.652648 & 0.0013 \\
\hline $\mathrm{C}$ & -15.896591 & 3.443627 & -4.616235 & 0.0001 \\
\hline
\end{tabular}

Source: Authors using Eviews software.

NB: The significance of the coefficients at $5 \%$ is indicated by *.

A simple reading of these tables shows that in the short term the debt cancellation is positive and significant, meaning that it has positive effects on economic growth in the Republic of Congo; while in the long term it is negative and significant, therefore it has negative effects on economic growth in the Republic of Congo in the long term. Moreover, the CointEq(-1) coefficient corresponding to the recall force is negative (-0.32) and significant at the $5 \%$ threshold $(\mathrm{p}=0.000)$. This shows that there is indeed an adjustment mechanism towards long-term equilibrium.

In view of the results obtained above, it appears that the model selected is of good quality and can be further discussed.

\section{ii. Discussion of the results}

Two lessons can be drawn from the results of the model estimation: debt cancellation has both positive and negative effects on economic growth in the Republic of Congo.

In the short term, the positive impacts of debt cancellation on economic growth in the Republic of Congo can be observed. Indeed, the results show that the coefficient associated with the debt cancellation variable is positive (0.0388) and significant (0.040) at the 5\% threshold. What this means is that economic growth in the Republic of Congo reacts positively to debt cancellation, given that in 2010, when Congo acceded to the HIPC initiative, it had a real GDP growth rate of $8.7 \%$. Thus, a $1 \%$ increase in debt cancellation, all other things being equal, leads to a $0.04 \%$ increase in the level of economic growth in the Republic of Congo. This result corroborates those of Abdelhafidh (2008), Ekperiware and Oladeji (2012), and Marcelino and Hakobyan (2014), and confirms the theories of debt overhang and eviction.

In the long term, the negative impacts of debt cancellation on economic growth in the Republic of Congo can be observed. In fact, according to the long-term results, the coefficient associated

with the debt cancellation variable is negative (-0.45) and significant $(0.01)$ at the $5 \%$ threshold. This means that debt cancellation has a negative impact on economic growth in the Republic of Congo. Reason why economic activity slowed from 2011 in a context marked by a decrease in the amounts relating to the debt cancellation, with growth rates for 2011, 2012 and 2013 of $3.4 \%, 3.8 \%$ and $3.3 \%$ respectively. This result confirms the reputation effect theory.

\section{Conclusion and economic policy implications}

The objective of this work was to determine the effects of the cancellation of the external public debt on economic growth in the Republic of Congo. The results obtained through the ARDL method, using quarterly timelines data from 1990 to 2016, shows that debt cancellation has positive impacts on growth in the short term but negative impacts in the long term. This can be explained by the fact that the debt cancellation covers a well-defined period.

These results invalidate the hypothesis of this work, since the effects of cancellation on economic growth in the Republic of Congo are not the same in the short term as in the long term. Thus, the ability to find a positive impact of debt cancellation on growth in low-income countries corresponds to previous studies carried out (Ekperiware and Oladji (2012), Marcelino and Hakobyan (2014)). The results imply that, while high debt is assumed to dampen growth, a reduction in the outstanding debt through debt cancellation necessarily stimulates growth in the recipient country.

Moreover, the possibility of finding a positive impact of debt cancellation on growth should indeed motivate the international community to continue or strengthen its efforts in terms of cancelling the country's contractual obligations. However, the negative impacts of debt cancellation observed on Congolese economic growth in the long term can be explained by the fact that Congo has a narrow fiscal base, with exports based on a few commodities subject to highly fluctuating markets. As a result, there is a risk that the funds generated by debt cancellation could be used to finance expenditures other than those related to the social sector and the revival of economic activity. Therefore, the Congolese authorities should ensure that the funds generated by debt cancellation initiatives are optimally directed towards productive investments. On the other hand, they should adopt rational policy frameworks to promote efficient revenue generation by broadening the Republic of Congo's export base. 


\section{References}

[1] Abdelhafidh S. (2008), «Réduction de la dette extérieure et Croissance économique dans les pays africains à faible revenu », Université de Sousse.

[2] Bakare A. (2010), "Debt Forgiveness and its Impact on the Growth of Nigerian Economy: An Empirical Study", Pakistan Journal of Social Sciences, Vol. 7, No. 2, pp. 34-39.

[3] Barro, R. J (1999), "Human Capital and Growth in Cross-country Regressions" Swedish Economic Policy Review, pp. 237-277

[4] Bulow J. and Rogoff K. (1989), "A Constant Reconstruction Model of Sovereign Debt", Journal of Political Economy, Vol. 97, pp. 155-178.

[5] Cairnes J.E. (1874), Some Leading Principles of Political Economy Newly Expounded, McMillan.

[6] Cohen D. (1993), "Low Investment and Large LDC Debt in the 1980's", The American Economic Review, Vol. 83, No. 3, pp.437-449.

[7] Corden W. M. (1988), "Debt Relief and Adjustment Incentives", IMF Staff Papers, December, vol.85, pp.628-643.

[8] Easterly W. (2002), "How Did Heavily Indebted Poor Countries Become Heavily Indebted? Reviewing Two Decades of Debt Relief' World Development, vol.30, $\mathrm{n}^{\circ} 10$, October, pp.1677-1696.

[9] Ekperiware M. and S. I. Oladeji (2012), "External Debt Relief and Economic Growth in Nigeria", American Journal of Economics, vol. 2, No. 7, pp.195-205

[10] Johansson P. (2010), "Debt Relief, Investment and Growth", World Development, vol.38, n 9 , September, pp.1204-1216.

[11] Krugman P. (1988), "Financing vs. Forgiving a Debt Overhang", Journal of Development Economics, vol.29, n³, nov, pp.253-268.

[12] Madhur Gautam (2003) «Allègement de la dette pour les plus pauvres
[13] Examen OED de l'initiative PPTE », The World Bank, Washington, D.C.

[14] Mankiw, N. G., D. Romer and D. N. Weil (1992), "A Contribution to the Empirics of Economic Growth" Quarterly Journal of Economics, vol.107, n² 2 , may, pp.407-437.

[15] Marcelino Sandra R. and HakobyanIvetta (2014), "Does Lower Debt Buy Higher Growth? The Impact of Debt Relief Initiatives on Growth", IMF Working Paper, 14/230.

[16] PNUD (2012), «Etude sur la vulnérabilité de la dette de l'économie congolaise et ses perspectives de diversification ».

[17] Presbitero, A. F. (2009), "Debt Relief Effectiveness and Institution Building; Universit aPolitecnicadelle Marche - Department of Economics; 4th December 2008 Online at http://mpra.ub.uni-uenchen.de/12597/MPRA Paper No. 12597.

[18] Sachs, J. (1989), "The Debt Overhang of Developing Countries", in Calvo, G. et al (eds.) Debt Stabilization and Development: Essays in Memory of Carlos Diaz Alejandro Basil Blackwell, Oxford, pp.80-102.

[19] Servén, L. (1997), “Uncertainty, Instability, and Irreversible Investment: Theory, Evidence, and Lessons for Africa”, PRE Working Paper $\mathrm{N}^{\circ}$ I722, the World Bank, February 1997

[20] Solow, R. (1956), "A Contribution to the Theory of Economic Growth", Quarterly Journal of Economics, vol.10, july, pp 319-365.

[21] Stern, Nicholas (2002), "Making the Case for Aid in World Bank" in A Case for Aid: Building a Consensus for Development Assistance" Washington, The World Bank.

[22] Victor E. T., Johan L. and Cheh K., (2009), "Has Debt Relief Been Beneficial To The Economic Growth of Africa?", School of Sustainable Development of Society and Technology, Malardalen University. 